\title{
IDENTIFICATION AND PATHOGENICITY OF FUSARIUM SPP. ISOLATED FROM FLAX ROOTS
}

\author{
ALY, A. A. ${ }^{1}$, E. M. HUSSEIN ${ }^{1}$, A. A. EL-AWAMRI ${ }^{2}$, M. T. M. MANSOUR ${ }^{1}$, \\ And MARIAN M. HABEB ${ }^{1}$
}

\author{
1. Plant pathology Res. Instit., ACR, Giza, Egypt. \\ 2. Botany Department, Faculty of Science, Ain Shams University, Cairo, Egypt.
}

(Manuscript received 10 July 2016)

\begin{abstract}
$\mathrm{S}$ even different fungi were isolated from the necrotic root tissues of infected Flax seedlings or older plants. Samples used in isolation were randomly collected from the experimental flax plots at Giza Agricultural Research Station. Fusarium spp. were isolated most frequently comprising $41.09 \%$, while frequencies of isolation of the other fungi ranged from 1.00 to $23.97 \%$. Regression analysis revealed that root colonization incidence (RCI) and root colonization severity (RCS) and relationship of rootcolonizating fungi of flax conformed to the linear model. According to the generated model, RCI accounted for $89.8 \%$ of the total variation in RCS. A total of 52 randomly selected isolates from infected roots were tested for pathogencity on flax cultivar Sakha 1 under greenhouse conditions. The results of pathogenicity test demonstrated that Fusarium spp. are the major causal agents of flax seedling blight as they accounted for $54 \%$ of the pathogenic isolates in the test. A total of 103 monosporic Fusarium isolates were randomly colleced from eight governorates and identified to species level. F.oxysporum $(63.60 \%)$ and F.solani $(27.35 \%)$ were the most predominant species. Other species were F.moniliforme (3.88\%), F.lateritium(1.04\%), F.semitectum $(0.66 \%)$ and unidentified Fusarium spp. (3.49\%). RCI and RCS relationship of rootcolonizing fusaria of flax conformed to the linear model. According to the generated model, RCI accounted for $75.3 \%$ of the total variation in RCS. Of the 103 isolates, a random sample of 32 isolates were tested for pthogenicity on seedlings of flax cultivar Giza 10 under greenhouse conditions. The results of the pathogenicity test showed that $66.67 \%$ of pathogenic isolates belonged to F.oxysporum, while $33.33 \%$ belonged to F.solani. The high frequencies F.oxysporum and F.solani and their ability to cause considerable losses during seedling stage, strongly suggest that they are the most important fusaria involved in the etiology of seedling blight and root rot of flax in Egypt. Grouping the isolates of F.oxysporum, F.solani, and F.lateritium by cluster analysis, based on their virulence patterns was neither related to their geographic origins nor to species.
\end{abstract}

Key words: Linum usitatimum, Fusarium spp., pathogenicity geographic distribuation, and root colonization. 


\section{INTRODUCTION}

Flax (Linum usitatissimum L.) is the most important bast fiber crop in Egypt, ranking second after cotton (seedy fiber) in terms of economic importance and production. There has been a steady increase in flax production owing to the growing trend back to natural fibers for textiles.(El-Hawary, 2008). Flax production is currently confined to the Nile Delta governorates. Seedling blight and root rot are common in flax fields throughout the Nile Delta. However, if affected seedlings are killed early in the season, they may become wind-blown or rained out and their loss is hardly noticed (A.A. Aly, personal observation). Flax seed is delicate and the outer coat is easily damaged during threshing. Small cracks, which may not be obvious unless the seed is inspected under a magnifying glass, allow easy penetration of microorganisms unless the seed is protected with a fungicide. Untreated cracked seeds may rot quickly without germination, or they may germinate, producing weak seedlings that succumb quickly to attack by the microorganisms that cause blight. Plants affected by seedlings blight may occur singly or in patches. The roots of recently attacked plants show red to brown lesions, but within a few days they shrivel and turn dark. Root rot symptoms usually appear on older plants after the flowering stage. Plants turn brown prematurely and usually set few or no seeds. The underground portion of the stem and the roots are discolored and the root system may be stunted (Marten et al.,1984).

Fusarium species are economically important plant pathogens. Many species are also endophytic or saprophytic colonizers. As pathogens, Fusarium species cause a wide range of diseases on field, horticultural, and forest crops (Summerell et al., 2003). More than 80 economically important plants are affected by at least one disease caused by Fusarium (Leslie \& Summerell, 2006) Fusarium species; however, are often present as endophytes in many crops in agricultural ecosystems (Kuldau \&Yates, 2000). They can occupy the internal plant tissue without causing any symptoms, but may induce disease symptoms when the plants are subjected to drought or other stress factors (Burgess, 1981).

Fusarium spp. occur frequently among the fungal microflora associated with diseased flax roots and are a major cause of seedling blight and root rot in some countries (Gruzdeviene et al., 2008). In Egypt, although Fusarium spp. are frequently and easily isolated from blighted flax seedlings and rotted roots of adult plants, little attention has been given to their taxonomy and their role in the etiology of seedling blight and root rot. 
Invasion of flax roots by soil-borne fusaria diminishes the plant's capacity for efficient nutrient and water uptake. Damage caused by these pathogens is difficult to assess from year to year due to differences in location, crop management, and climatic factors. Recognition of the role of soil-borne fusaria as a limiting factor for flax production potential in the Nile Delta is problematic due to a focus on more visible foliar disease. Identification and quantification of root-invading fusaria involve more laborious procedures than the simple visual observation needed to detect and quantify the presence of foliar pathogens (Tunali et al., 2008).

The main objectives of this investigation were to identify Fusariam spp. associated with seedling blight and root rot of flax and to evaluate their pathogenicity to flax seedlings under greenhouse conditions. For comparison, isolation frequencies and pathogenicity of other fungi from flax roots were also evaluated to develop more effective control strategies.

\section{MATERIALS AND METHODS}

\section{Isolation, identification, and quantification of Fusarium spp. and other fungi from flax roots.}

Diseased flax plants at seedling stage through maturity were collected at random from 20 experimental sites (one sample/site) at Giza Agricultural Research station during 2012. Each sample included from 20 to 30 seedlings affected with a variety of damping-off symptoms or rotted roots of 10 to 15 adult plants. The flax genotypes sampled were not determined for all sites because it is known that the genotypes grown in Egypt are all susceptible to seedling blight and root rot (A.A.Aly, personal observation ). The seedlings and roots collected at each site were stored at $4^{\circ} \mathrm{C}$ until fungal isolation was performed. Seedling and roots of mature plants were washed thoroughly under running tap water for $24 \mathrm{hr}$ to remove any adhering soil. Small pieces (approximately $0.5 \mathrm{~cm}$ long) of necrotic root tissues were surface sterilized with $10 \%$ Clorox solution for 2 minutes, and washed several times with sterilized water. The surface- sterilized pieces were then blotted dry between sterilized filter papers and plated ( 5 pieces/plate) onto potato -dextrose agar (PDA) medium amended with streptomycin sulfate (killebrew et al., 1993) or penicillin G. and rose bengal (100-200 mg/L each) as bacterial inhibitors. The plates were incubated at $26 \pm 3^{\circ} \mathrm{C}$ for 3-7 days. The developing colonies were identified according to Gilman (1966). Colonies of each fungus were expressed as percentage of the total developing 
colonies. Pure isolates, selected at random for pathogenicity test, were grown on PDA in petri dishes.

\section{Pathogenicity of Fusarium spp. and other fungi isolated from experimental plots.}

Substrate for growth of each selected isolate was prepared in $500 \mathrm{~mL}$ glass bottle, each bottle contained $50 \mathrm{~g}$ of sorghum grains and $40 \mathrm{~mL}$ of tap water. Contents of bottles were autoclaved for 30 minutes. Isolate inoculum, taken from oneweak-old culture on PDA, was aseptically introduced into the bottle and allowed to colonize sorghum for 3 weeks. The test was carried out by using autoclaved clay loam soil. Batches of soil were infested separately with inoculum of each isolate at a rate of $50 \mathrm{~g} / \mathrm{Kg}$ of soil. Infested soil was dispensed in $10-\mathrm{cm}$-diameter clay pots and these were planted with 20 seeds per pot (cultivar Sakha 1). In the control treatments, sterilized sorghum grains were mixed throughtly with soil at a rate of $50 \mathrm{~g} / \mathrm{Kg}$ of soil. Pots were randomly distributed on greenhouse benches. The greenhouse was equipped with a heating system assuring that the minimum temperature in the greenhouse was maintained at $28^{\circ} \mathrm{C}$; however, due to the lack of a cooling system, the maximum temperature could not be controlled fluctuating from 30 to $35^{\circ} \mathrm{C}$ depending on the ambient temperature during the day (the tests were conducted in January and February 2013). Dead seedlings (combined pre-emergence and postemergence damping-off) were recorded 45 days after planting. Pathogenicity test was repeated once.

\section{Survey of Fusarium spp. isolated from commercial flax fields in eight governorates}

A random sample of 103 Fusarium isolates were isolated from commercial flax fields in eight governorates. Isolation, Purification, and quantification of the isolates were carried out as previously mentioned. The isolates were identified to species level according to Booth (1971).

\section{Pathogenicity of a selected group of Fusarium isolates from commercial flax fields}

Of the 103 isolates, a random sample of 32 isolates were subcultured on PDA medium for pathogenicity test, which was carried out as previously described. 


\section{Statistical analysis of the data}

The experimental design of all the pathogenicity tests was a randomized complete block with five replicates. Analysis of variance (ANOVA) of the data was performed with the MSTAT-C Statistical Package. Duncan's multiple range test and least significant difference (LSD) were used to compare between isolate means. Percentage data were transformed into arcsine angles before carrying out the ANOVA to normalize data and stabilize variances throughout the data range. Correlation, regression, and cluster analysis were performed with the software package (SPSS $6.0)$.

\section{RESULTS}

Seven different fungi were isolated from the necrotic root tissues of affected seedlings or older plants, but Fusarium spp. were isolated most frequently comprising $41.09 \%$ of all fungi isolated, while frequencies of isolation of the other fungi ranged from 1.00 to $23.97 \%$ (Table 1 ). No attempt was made to separate fungi on the basis of their association with seedlings versus older plants ; however, the isolation of fungi from both seedlings and older plants suggested that prolonged colonization of roots is perhaps the greatest threat posed by fungi, particularly Fusarium spp.,for flax health.

In the present study, root colonization severity (RCS) of flax by fungi was estimated by a method involving objective judgment (Table 2); however, the method was tedious and time-consuming. Estimating RCS indirectly from root colonization incidence (RCI), which was more easily acquired and more precise (Table 1), may reduce some of these problems. Regression analysis (Table 2 and Fig. 1) revealed that RCI and RCS relationship of root- colonization fungi of flax conformed to the linear model. According to the generated model, RCI accounted for $89.8 \%$ of the total variation in RCS.

Associations among the pairs of fungi isolated from flax roots were identified and the relative strength of these associations were measured by calculating Pearson's correlation coefficient ( $r$ ) for each pair of fungi . A total of 21 fungal pairings were analysed (Table 3 ). Three $(14.3 \%)$ of the fungal pairs were significantly associated. Of the three pairs, two were negatively associated and one was positively associated. No significant associations were found in the remaining fungal pairs.

A total of 52 randomly selected isolates were tested for pathogenicity under greenhouse condition (Table 4). Fusarium isolates represented $51.92 \%$ of the tested 
isolates (Table 5). The prevailing environmental conditions during the test were favourable for infection. Thus, all the tested isolates, with isolates 28 and 35 of Alternaria, being less pathogenic (Table 4). The results of pathogenicity test demonstrated convincingly that Fusarium spp. are the major causal agents of flax seedling blight and root rot in the experimental sites as they accounted for $54 \%$ of the pathogenic isolates in the test.

A total of 103 Fusarium isolates were randomly collected from eight governorates and identified to the species level (Table 6). F.oxysporum Schlecht. $(63.60 \%)$ and F.solani (Mart.) Sacc. (27.35 \%) were the most predominant species. Other species were F.moniliforme Sheld. (3.88\%), F.lateritium Nees (1.04\%), F.semitectum Berk and Ravenel (0.66 \%), and unidentified Fusarium spp. (3.49\%)

RCI and RCS (Table 7) relationship of root-colonizing fusaria of flax conformed to the linear model. According to the generated model, RCI accounted for $75.3 \%$ of the total variation in RCS (Table 8 and Fig. 2 ).

Isolation frequency of F.oxysporum was negatively correlated with each of isolation frequency of F.solani and F.moniliforme. The other correlation coefficients shown in (Table 9) were all nonsignificant.

A random sample of 32 monosporic isolates was tested for pathogenicity on seedlings of flax cultivar Giza 10 (Tables 10 and 11 ). Fourteen (43.75\%) of the tested isolates came from east Delta region.

Data in table (12) showed that the minority of F.oxysporum (33.33\%) and the majority of F.solani isolates (57.14\%) were pathogenic. On the other hand, the majority of the pathogenic isolates as a whole $(66.67 \%)$ belonged to F.oxysporum, while the minority $(33.33 \%)$ belonged to F.solani. Regarding any of the tested variables in table (13), the percentage of pathogenic isolates within F.solani was always greater than that in F.oxysporum. It is worth noting that some of the pathogenic isolates significantly reduced the percentage of surviving seedling. Therefore, less competition occurred among seedlings in the pots infested with these isolates leading to significant increases in dry weight. Data in table (14) are consistent with those of tables (12) and (13) in that F.solani appear to be the most pathogenic Fusarium to flax roots in Egypt. A highly significant negative correlation was always observed between survival and each of pre- and postemergence damping-off (Table 15). A significant negative correlation was observed between survival and dry weight only in the case of F.solani . 
A phenogram based on dissimilarity distance (DD), generated from cluster analysis of virulence patterns of Fuarium isolates, is presented in Fig. (3). The smaller the $\mathrm{DD}$, the more closely the isolates were related in their virulence patterns. Two groups of similar isolates were identified. The first group $(D D=0.0)$ included 25 isolates while the second group $(D D=11.0)$ included five isolates. The virulence patterns of isolates 10 and 14 were quite different from the others. Although the first group of isolates were identical in their virulence patterns, they belonged to F.oxysporum, F.solani, and F.lateritium. These isolates also came from different governorates. Thus, it seems reasonable to conclude that grouping the isolates by cluster analysis was neither related to their geographic origins nor species.

\section{DISCUSSION}

In the present study, Fusarium spp. were isolated from flax roots collected from widely separated governorates. This may indicate that Fusarium spp.are well adapted to colonize flax roots under a wide range of environmental conditions (edaphic factors, crop rotations, irrigation systems, temperature regimes, and so on).

Basic knowledge of the relationship between RCI and RCS must be obtained before RCI can be efficiently used as a measure of RCS (Rouse et al., 1981). Several models have been used to describe the relationship between disease incidence and disease severity in plant diseases (Seem, 1984); however, there have been no reports of this type of study on root-colonization fungi of flax.

In the present study, regression analysis revealed that RCI and RCS relationship of root-colonization fungi of flax conformed to the linear model.

The occurrence and associations of pathogen species are of a central importance in the ecology of host-pathogen interactions in complex pathosystems, i.e. those with multiple pathogens on a single or multiple hosts. Within such pathosystems, biotic and abiotic factors influence the distribuation and abundance of pathogen species. Subsequently, patterns of association result from interrelationships among organisms and also environmental factors. These patterns depend on whether or not organisms select or avoid the same habitat, have same mutual interaction or repulsion, or have no interaction (Nelson \& Campbell, 1992).To the best of our knowledge, no attempts have been made to study the associations among fungi isolated from flax roots.

However, one should keep in mind that the significant $r$ values, as we have demonstrated herein for some fungal pairs, shoud be interpreted with caution (Gomez 
\& Gomez,1984) because the existence of a process may not be proved by the existence of a pattern (Nelson \& Campbell, 1992), i.e., the significant $r$ value does not necessarily prove that one fungus is beneficial or detrimental to another. Thus, the primary utility of the correlation technique is to identify the potentially interactive fungi. However, the interpretation of the nature of such an interaction requires information on the ecological requirements and biological attributes of each member of the interacting pair. In spite of these limitations, certain general conclusions could be drawn. A negative association between two fungi may have resulted because each fungus had distinct environmental and resource requirements or, perhaps displayed competitive exclusion or antagonism. Fungi that share specialized niche requirements often occur together and would primarily exhibit a positive association.

Our personal experience with seedling blight and root rot of flax indicated that the use of standard isolation techniques often results in the frequent recovery of fungi normally considered saprophytic. This was especially true of samples that included severely affected seedlings or older plants. Therefore, the pathogenicity tests employed in this study were not intended to simulate natural conditions. On the contrary, they were deliberately designed to provide for maximum expression of pathogenicity. The soil was autoclaved, the temperature was optimum most of the time, and the isolates inoculum was relatively high. Thus, those isolates incapable of producing statistically significant levels of damping-off, under these very favourable environmental conditions, were considered to be nonpathogenic. This seemed a reasonable approach to ensure inclusion of any potential incitants of seedling blight or root rot, which are widely considered to be complexes of several fungi including Fusarium spp. (Gruzdeviene et al., 2008).

The nonspecialized Fusarium spp. involved in flax seedling blight have a wide host range, therefore, rotation of flax with other crops is a questionable practice for the disease control (Nyvall,1981). Control of flax seedling blight by selection of blight resistant cultivars has not been emphasized in the development of commercial flax cultivars because of the lack of sources of such a resistance. Consequently, seedling blight of flax is controlled largely by using seed-dressing fungicides (Khalil et al., 1992). Effective seed treatment relies on up-to-date information on the major causal agents of diseases. Results of this study indicate that the selection of seed-dressing fungicides to control flax seedling blight should include compounds targeted mainly at Fusarium spp. 
Survey of root-colonizing fungi of flax included several fungi not previously reported as root pathogens of flax. Macrophomina phaseolina was recorded on flax for the first time anywhere, and Alternaria spp., Aspergillus spp., and Curvularia spp. for the first time in Egypt. It is worth noting that although Alternaria spp. and Aspergillus spp. were found in low frequencies, they included pathogenic isolates capable of killing flax seedlings in the pathogenicity test (Table 4). $R$. solani has been described as non-specialized and highly virulent (Ogoshi, 1987). In our pathogenicity test (Table 4), all $R$. solani isolates were moderately pathogenic (37 to $55 \%$ damping off).

Most of unidentified isolates were found in their non-spore-producing forms. Therefore, we were unable to identify them based on these vegetative (mycelia) phases. Further research is needed to identify these isolates especially if one takes into account that they represented $16 \%$ of the total pathogenic isolates in the pathogenicity test (Table 4).

The results of pathogenicity test also revealed that $62.5 \%$ of Fusarium spp. isolates were nonpathogenic (Table 11). This lack of pathogenicity does not necessarily mean that these isolates are unimportant in the agricultural ecosystem. In fact, they are either endophytic or saprophytic colonizers of flax root. Nonpathogenic isolates of Fusarium spp. have been reported to control Fusarium wilt on various crops (Alabouvette et al., 1998). Endophytic isolates can occupy the internal plant tissue without causing any symptoms, but may induce disease symptoms when the plants are subjected to drought or other stress factors (Burgess, 1981).

The predominance of F.oxysporum in our random sample agrees with other reports, which indicate that this species makes up a major portion of the fungal flora. For example, Gordon (1956) found that F.oxysporum was by far the most prevalent species of Fusarium as it represented approximately $67 \%$ of Fusarium spp. in Canadian soil. Meyer (1967) showed that the relative abundance of F.oxysporum may be as high as $8-10 \%$ of the soil total fungal population. In the rhizosphere, the relative abundance of F.oxysporum may reach $43 \%$ of the total microfungal population while on the root surface or in its superficial layers, F.oxysporum is even more abundant, and its frequency among isolates may reach 97\% (Meyer, 1967).

The high frequency of F.oxysporum and F.solani and their ability to cause considerable losses during seedling stage strongly suggest that they are the most important pathogenic fusaria involved in the etiology of seedling blight and root rot flax in Egypt. 
Table 1. Frequency of Fusarium spp. compared with frequencies of other fungi isolated from roots of flax plants infected with postemergence damping - off or root rot.

\begin{tabular}{|c|c|c|c|c|}
\hline \multirow{2}{*}{ Fungus } & \multicolumn{2}{|c|}{ Samples $^{\mathrm{a}}$ from which fungus was isolated } & \multicolumn{2}{|c|}{ Isolation frequency } \\
\hline & NO. & $\%^{\mathrm{b}}$ & $(\%)^{c}$ & transformed $^{d}$ \\
\hline Fusarium spp. & 18 & 90 & 41.09 & 38.13 \\
\hline Rhizoctonia solani & 10 & 50 & 10.19 & 13.38 \\
\hline Alternaria spp. & 6 & 30 & 6.22 & 8.02 \\
\hline Macrophomina phaseolina & 9 & 45 & 14.55 & 15.38 \\
\hline Aspergillus spp. & 1 & 5 & 1.00 & 1.33 \\
\hline Curvularia spp. & 1 & 5 & 2.00 & 1.96 \\
\hline Unidentified & 13 & 65 & 23.97 & 24.10 \\
\hline $\operatorname{LSD}(p \leq 0.05)$ & & & & 9.87 \\
\hline
\end{tabular}

${ }^{a}$ Twenty samples of flax roots were randomly collected in 2012 from experimental flax plots at Giza Agricultural Research Station.

${ }^{\mathrm{b}}$ Root colonization incidence

${ }^{\mathrm{C}}$ Root colonization severity, which indicates the number of colonies of a fungus expressed as the percentage of the total developing colonies from a sample, and each value is the mean of twenty samples.

${ }^{d}$ percentage data were transformed into arcsine angles before carrying out the analysis of variance to normalize data and stabilize variances throughout the data range. 
Table 2. Regression equation a that describes the relationship between root Colonization incidence $(X)$ and severity $(Y)$ of flax plants infected with postemergence damping -off or root rot.

\begin{tabular}{|lllll|}
\hline Regression equation & F.value & P $>$ F & $\mathbf{R}^{2}$ & $\mathbf{r}$ \\
\hline$Y=-3.8969+0.4355 X$ & 44.216 & 0.001 & 0.898 & 0.948 \\
\hline
\end{tabular}

${ }^{a}$ Regression equation was generated based on the number of samples from which Fusarium spp.and other fungi were isolated (Table 1).

Table 3. Correlation between frequencies of fungi isolated from roots of flax plants infected with postemergence damping - off or root rot.

\begin{tabular}{|l|l|l|l|l|l|}
\hline & & \multicolumn{2}{|c|}{ Isolation frequency of } & \multicolumn{2}{|c|}{4} \\
\hline Isolation frequency of & \multicolumn{1}{|c|}{1} & \multicolumn{2}{|c|}{5} \\
\hline 1.Fusarium spp. & & & & \\
\hline 2. Rhizoctonia solani & $-0.084^{\mathrm{a}}(0.726)^{\mathrm{b}}$ & & & \\
\hline 3.Alternaria spp. & $-0.209(0.375)$ & $-0.442(0.051)$ & & & \\
\hline 4.Macrophomina phaseolina & $-0.123(0.606)$ & $-0.021(0.931)$ & $-0.345(0.137)$ & & \\
\hline 5.Aspergillus spp. & $-0.395(0.085)$ & $-0.223(0.346)$ & $0.728(0.000)$ & $-0.185(0.436)$ & \\
\hline 6. Curvularia spp. & $-0.395(0.085)$ & $0.214(0.364)$ & $-0.134(0.573)$ & $-0.185(0.436)$ & $-0.053(0.826)$ \\
\hline 7.Unidentified & $-0.558(0.010)$ & $-0.160(0.500)$ & $0.002(0.994)$ & $-0.387(0.092)$ & $-0.044(0.854)$ \\
\hline
\end{tabular}

${ }^{a}$ Pearson's correlation coefficient.

${ }^{b}$ Probability level and $n=20$. 
Table 4. Pathogenicity aof Fusarium spp. Compared with pathogenicity of other fungi isolated from roots of flax plants infected with postemergence damping-off or root rot.

\begin{tabular}{|c|c|c|}
\hline Fungus & Isolate no. & Damping-off(\%) ${ }^{c}$ \\
\hline \multirow[t]{27}{*}{ Fusarium spp. } & 2 & $34 \mathrm{~A}-\mathrm{F}$ \\
\hline & 4 & $42 \mathrm{~B}-\mathrm{F}$ \\
\hline & 5 & 54 A-E \\
\hline & 6 & 55 A-E \\
\hline & 7 & $32 \mathrm{D}-\mathrm{F}$ \\
\hline & 8 & $60 \mathrm{~A}-\mathrm{D}$ \\
\hline & 9 & $34 \mathrm{C}-\mathrm{F}$ \\
\hline & 12 & $43 \mathrm{~B}-\mathrm{F}$ \\
\hline & 13 & $60 \mathrm{AB}$ \\
\hline & 14 & 56 A-D \\
\hline & 15 & $46 \mathrm{~A}-\mathrm{F}$ \\
\hline & 17 & $51 \mathrm{~A}-\mathrm{F}$ \\
\hline & 19 & $51 \mathrm{~A}-\mathrm{F}$ \\
\hline & 20 & $62 \mathrm{~A}-\mathrm{C}$ \\
\hline & 21 & $69 \mathrm{~A}$ \\
\hline & 23 & 57 A-D \\
\hline & 25 & $39 \mathrm{~B}-\mathrm{F}$ \\
\hline & 26 & $52 \mathrm{~A}-\mathrm{F}$ \\
\hline & 27 & 48 A-E \\
\hline & 31 & $32 \mathrm{D}-\mathrm{F}$ \\
\hline & 39 & $40 \mathrm{~B}-\mathrm{F}$ \\
\hline & 40 & $40 \mathrm{~B}-\mathrm{F}$ \\
\hline & 41 & $35 \mathrm{C}-\mathrm{F}$ \\
\hline & 42 & $42 \mathrm{~B}-\mathrm{F}$ \\
\hline & 46 & $45 \mathrm{~B}-\mathrm{F}$ \\
\hline & 49 & $40 \mathrm{~B}-\mathrm{F}$ \\
\hline & 52 & $\begin{array}{l}50 \mathrm{~A}-\mathrm{F} \\
\text { (Continued on next page) }\end{array}$ \\
\hline
\end{tabular}


Table 4. (Continued from preceding page)

\begin{tabular}{|c|c|c|}
\hline Fungus & Isolate no. & Damping - off (\%) \\
\hline \multirow{9}{*}{ Alternaria spp. } & 3 & $41 \mathrm{~B}-\mathrm{F}$ \\
\hline & 22 & $56 \mathrm{~A}-\mathrm{D}$ \\
\hline & 24 & $46 \mathrm{~A}-\mathrm{F}$ \\
\hline & 28 & $27 \mathrm{E}-\mathrm{G}$ \\
\hline & 34 & $39 \mathrm{~B}-\mathrm{F}$ \\
\hline & 35 & $25 \mathrm{FG}$ \\
\hline & 37 & $36 \mathrm{C}-\mathrm{F}$ \\
\hline & 50 & $51 \mathrm{~A}-\mathrm{F}$ \\
\hline & 51 & 59 A-D \\
\hline \multirow[t]{5}{*}{ Rhizoctonia solani } & 29 & $47 \mathrm{~A}-\mathrm{F}$ \\
\hline & 33 & $37 \mathrm{~B}-\mathrm{F}$ \\
\hline & 38 & $40 \mathrm{~B}-\mathrm{F}$ \\
\hline & 43 & $55 \mathrm{~A}-\mathrm{E}$ \\
\hline & 47 & $45 \mathrm{~B}-\mathrm{F}$ \\
\hline \multirow[t]{2}{*}{ Aspergillus spp. } & 16 & $56 \mathrm{~A}-\mathrm{D}$ \\
\hline & 44 & $51 \mathrm{~A}-\mathrm{F}$ \\
\hline Stemphylium sp. & 10 & $45 \mathrm{~A}-\mathrm{F}$ \\
\hline \multirow[t]{8}{*}{ Unidentified } & 1 & $54 \mathrm{~A}-\mathrm{E}$ \\
\hline & 11 & $51 \mathrm{~A}-\mathrm{F}$ \\
\hline & 18 & 32 D-F \\
\hline & 30 & $49 \mathrm{~A}-\mathrm{F}$ \\
\hline & 32 & $47 \mathrm{~A}-\mathrm{F}$ \\
\hline & 36 & $47 \mathrm{~A}-\mathrm{F}$ \\
\hline & 45 & $51 \mathrm{~A}-\mathrm{F}$ \\
\hline & 48 & $47 \mathrm{~A}-\mathrm{F}$ \\
\hline Control $^{d}$ & $\ldots$ & $10 \mathrm{G}$ \\
\hline
\end{tabular}

a Pathogenicity of the tested fungi was evaluated on seedling of flax cultivar Sakha1 under greenhouse condition in 2013.

b samples of flax roots used in isolation were randomly collected in 2013 from experimental flax plots at Giza Agricultural Research Station.

${ }^{c}$ combined preemergence and postemergence.Percentage data were transformed into arcsine angles before carrying out the analysis of variance to normalize data and stabilize variances throughout the data range.Each value is the mean of five replicates(pots).Means followed by the same letter(s)are not significantly different ( $\mathrm{P} \leq 0.05$ )according to Duncan's multiple range test.

${ }^{\mathrm{d}}$ Autoclaved soil was mixed with autoclaved sorghum. 
Table 5. Distribution of pathogenic isolates of Fusarium spp.and other fungi isolated from flax roots.

\begin{tabular}{|l|c|c|c|c|}
\hline \multirow{2}{*}{ Fungus } & Total number of & $\begin{array}{c}\text { Percentage of } \\
\text { isolates }\end{array}$ & Percentage of & Percentage of \\
& $\begin{array}{c}\text { Pathogenic } \\
\text { isolates }\end{array}$ & Within fungus & Pathogenic \\
isolates
\end{tabular}

${ }^{\text {aA }}$ total of 52 isolates were tested for pathogenicity on sakha 1 flax seedlings under greenhouse conditions in 2013.The details of pathogenicity test are shown in table (4). 
Table 6. Survey of Fusarium spp. isolated from flax roots in 2013.

\begin{tabular}{|c|c|c|c|c|c|c|c|}
\hline \multirow[b]{2}{*}{ Governorate } & \multicolumn{7}{|c|}{ Fusarium } \\
\hline & $\begin{array}{c}F . \\
\text { oxysporum }\end{array}$ & $\begin{array}{c}F . \\
\text { solani }\end{array}$ & $\begin{array}{c}F . \\
\text { moniliforme }\end{array}$ & $\begin{array}{c}F . \\
\text { lateritium }\end{array}$ & $\begin{array}{c}F . \\
\text { semitectum }\end{array}$ & $\begin{array}{c}F . \\
\text { unidentified }\end{array}$ & Total \\
\hline Beheira & $12^{\mathrm{a}}$ & 3 & 1 & 0 & 0 & 0 & 16 \\
\hline (West Delta Region) & $75.0 \%^{\mathrm{b}}$ & $18.8 \%$ & $6.3 \%$ & $0.0 \%$ & $0.0 \%$ & $0.0 \%$ & \\
\hline Damietta & 4 & 3 & 0 & 0 & 0 & 0 & 7 \\
\hline (East Delta Region) & $57.1 \%$ & $42.9 \%$ & $0.0 \%$ & $0.0 \%$ & $0.0 \%$ & $0.0 \%$ & \\
\hline Daqahliya & 12 & 5 & 0 & 0 & 1 & 1 & 19 \\
\hline (East Delta Region) & $63.2 \%$ & $26.3 \%$ & $0.0 \%$ & $0.0 \%$ & $5.3 \%$ & $5.3 \%$ & \\
\hline Gharbiya & 6 & 8 & 3 & 0 & 0 & 0 & 17 \\
\hline (Middle Delta Region) & $35.3 \%$ & $47.1 \%$ & $17.6 \%$ & $0.0 \%$ & $0.0 \%$ & $0.0 \%$ & \\
\hline Giza & 9 & 1 & 0 & 1 & 0 & 1 & 12 \\
\hline (Middle Egypt Region) & $75.0 \%$ & $8.3 \%$ & $0.0 \%$ & $8.3 \%$ & $0.0 \%$ & $8.3 \%$ & \\
\hline Kafr El sheikh & 7 & 6 & 1 & 0 & 0 & 0 & 14 \\
\hline (North Delta Region) & $50.0 \%$ & $42.9 \%$ & $7.1 \%$ & $0.0 \%$ & $0.0 \%$ & $0.0 \%$ & \\
\hline Sharqiya & 9 & 2 & 0 & 0 & 0 & 0 & 11 \\
\hline (East Delta Region) & $81.8 \%$ & $18.2 \%$ & $0.0 \%$ & $0.0 \%$ & $0.0 \%$ & $0.0 \%$ & \\
\hline Unknouwn & 5 & 1 & 0 & 0 & 0 & 1 & 7 \\
\hline & 71.5 & $14.3 \%$ & $0.0 \%$ & $0.0 \%$ & $0.0 \%$ & $14.3 \%$ & \\
\hline Total & 64 & 29 & 5 & 1 & 1 & 3 & 103 \\
\hline
\end{tabular}

aNumber of isolates of Fusarium sp. from a governorate.

${ }^{\mathrm{b}}$ Number of isolates of Fusarium sp. expressed as the percentage of the total number of isolates of Fusarium spp. from a governorate 
Table 7. Frequency of Fusarium spp isolated from roots of flax plants infected with postemergance damping-off or root rot in 2013.

\begin{tabular}{|c|c|c|c|c|}
\hline \multirow[t]{2}{*}{ Fusarium } & \multicolumn{2}{|c|}{$\begin{array}{l}\text { Governorates }^{\mathrm{a}} \text { from which } \\
\text { Fusarium was isolated }\end{array}$} & \multicolumn{2}{|c|}{$\underline{\text { Isolation frequency }}$} \\
\hline & Number & $\%^{\mathrm{b}}$ & $\%^{\mathrm{c}}$ & Transformed $^{d}$ \\
\hline F.oxysporum & 8 & 100 & 63.60 & 52.21 \\
\hline F.solani & 8 & 100 & 27.35 & 30.74 \\
\hline F.moniliforme & 3 & 37.5 & 3.88 & 6.85 \\
\hline F.lateritium & 1 & 12.5 & 1.04 & 2.09 \\
\hline F.Semitectum & 1 & 12.5 & 0.66 & 1.66 \\
\hline Unidentified & 3 & 37.5 & 3.49 & 6.53 \\
\hline $\operatorname{LSD}(p \leq 0.05)$ & & & & 10.05 \\
\hline
\end{tabular}

a Isolates of Fasarium spp. were randomly isolated from commercial flax fields in eight governorates.

${ }^{\mathrm{b}}$ Root colonization incidence.

c Root colonization serverity, which indicates the number of Fusarium sp. isolates recovered from a governorate expressed as

the percentage of the total number of isolates of Fusarium spp. recovered from the governorate, and each value

is the mean of eight replicates (governorates).

d Percentage data were transformed into arcsine angles before carrying out the analysis of variance to normalize data and stabilize variances throughout the data range. 
Table 8. Regression equation ${ }^{a}$ that describes the relationship between root colonization incidence $(X)$ and severity $(Y)$ of flax plants infected with postemergence damping-off or root rot.

\begin{tabular}{|l|c|c|c|c|}
\hline Regression equation & F.value & $P>F$ & $R^{2}$ & $r$ \\
\hline$Y=-10.355+0.5405 X$ & 12.162 & 0.025 & 0.753 & 0.867 \\
\hline
\end{tabular}

a Regression equation was generated based on the number of governorates from which Fusarium spp. were isolated (Table 7).

Table 9. Correlation between frequencies of Fusarium spp. Isolated from roots of flax plants infected with postemergence dmping - off or root rot.

\begin{tabular}{|l|l|l|l|l|l|}
\hline \multicolumn{2}{|l|}{ Isolation frequency of } & 2 & 3 & 4 & 5 \\
\hline Isolation frequency of & 1 & 2 & & & \\
\hline 1. F.oxysporum & & & & & \\
\hline 2.F.solani & $-0.897^{\mathrm{a}}(0.003)^{\mathrm{b}}$ & & & & \\
\hline 3.F.moniliforme & $-0.763(0.028)$ & $0.611(0.108)$ & & & \\
\hline 4.F.lateritium & $0.297(0.475)$ & $-0.515(0.192)$ & $-0.248(0.554)$ & & $-0.143(0.736)$ \\
\hline 5.F.semitectum & $-0.010(0.980)$ & $-0.028(0.947)$ & $-0.248(0.554)$ & & \\
\hline 6.Unidentified & $0.348(0.398)$ & $-0.620(0.101)$ & $-0.452(0.260)$ & $0.360(0.381)$ & $0.136(0.749)$ \\
\hline
\end{tabular}

a Pearson's correlation coefficient.

b Probability level and $n=8$. 
Table 10. Fusarium isolates used in pathogenicity test.

\begin{tabular}{|c|c|c|c|c|}
\hline \multirow[b]{2}{*}{ Fusarium } & \multirow{2}{*}{$\begin{array}{c}\text { Isolate serial } \\
\text { No. } \\
\end{array}$} & \multirow{2}{*}{$\begin{array}{l}\text { Fusarium } \\
\text { Collection no. }\end{array}$} & \multicolumn{2}{|c|}{ Geographic origin } \\
\hline & & & Governorate & Region \\
\hline F.oxysporum & 1 & $5 / 1$ & Daqahliya & East Delta \\
\hline & 2 & $5 / 2$ & Daqahliya & East Delta \\
\hline & 3 & $5 / 3$ & Daqahliya & East Delta \\
\hline & 4 & 10 & Giza & Middle Egypt \\
\hline & 5 & 17 & Giza & Middle Egypt \\
\hline & 6 & 21 & Unknown & Unknown \\
\hline & 7 & 34 & Giza & Middle Egypt \\
\hline & 8 & 36 & Unknown & Unknown \\
\hline & 9 & 37 & Daqahliya & East Delta \\
\hline & 10 & 44 & Beheira & West Delta \\
\hline & 11 & 47 & Sharqiya & East Delta \\
\hline & 12 & 49 & Sharqiya & East Delta \\
\hline & 13 & 53 & Sharqiya & East Delta \\
\hline & 14 & 56 & Daqahliya & East Delta \\
\hline & 15 & 57 & Gharbiya & Middle Delta \\
\hline & 16 & 64 & Daqahliya & East Delta \\
\hline & 17 & 66 & Beheira & West Delta \\
\hline & 18 & 76 & Beheira & West Delta \\
\hline & 19 & 84 & Beheira & West Delta \\
\hline & 20 & 85 & Kafr El-Sheikh & North Delta \\
\hline & 21 & 88 & Daqahliya & East Delta \\
\hline & 22 & 104 & Sharqiya & East Delta \\
\hline & 23 & 141 & Daqahliya & East Delta \\
\hline & 24 & 154 & Kafr El-Sheikh & North Delta \\
\hline F.solani & 25 & 30 & Unknown & Unknown \\
\hline & 26 & 35 & Giza & Middle Egypt \\
\hline & 27 & 50 & Kafr El-Sheikh & North Delta \\
\hline & 28 & 90 & Gharbiya & Middle Delta \\
\hline & 29 & $90 / 1$ & Gharbiya & Middle Delta \\
\hline & 30 & 91 & Daqahliya & East Delta \\
\hline & 31 & 140 & Daqahliya & East Delta \\
\hline F.lateritium & 32 & 2 & Giza & Middle Egypt \\
\hline
\end{tabular}


Table 11. Pathogenicity of Fusarium spp. Isolated from flax roots on flax seedlings (cultivar Giza 10) under greenhouse conditions in 2014.

\begin{tabular}{|c|c|c|c|c|c|c|c|c|}
\hline \multirow[b]{2}{*}{ Fusarium } & \multirow{2}{*}{$\begin{array}{l}\text { Isolate } \\
\text { No. }\end{array}$} & \multicolumn{2}{|c|}{ Preemergence damping-off } & \multicolumn{2}{|c|}{ postemergence damping-off } & \multicolumn{2}{|c|}{ survival } & \multirow{2}{*}{$\begin{array}{l}\text { Dry weight } \\
\text { (mg/plant) }\end{array}$} \\
\hline & & $\%$ & Transformed $^{\mathbf{b}}$ & $\%$ & Transformed & $\%$ & Transformed & \\
\hline F.oxysporum & $5 / 1$ & $7^{a}$ & $13.65 *$ & 2 & 5.17 & 91 & 73.04 & 44.80 \\
\hline & $5 / 2$ & 10 & $16.49 *$ & 1 & 2.58 & 89 & 70.92* & 41.80 \\
\hline & 10 & 5 & 9.96 & 2 & 5.17 & 93 & 76.59 & 48.80 \\
\hline & 17 & 1 & 2.58 & 17 & $19.60 *$ & 82 & $69.29 *$ & 48.80 \\
\hline & 21 & 3 & 7.75 & 13 & 14.74 & 84 & 72.47 & 48.80 \\
\hline & 34 & 2 & 5.17 & 5 & 9.73 & 93 & 76.94 & 46.80 \\
\hline & 36 & 5 & 9.96 & 3 & 7.75 & 92 & 75.48 & $44.0 \cdot$ \\
\hline & 37 & 2 & 3.69 & 3 & 6.27 & 95 & 82.10 & 50.60 \\
\hline & 44 & 5 & 7.90 & 88 & $72.23 *$ & 7 & $9.87 *$ & 22.0 . \\
\hline & 47 & 9 & $14.86 *$ & 38 & $36.84 *$ & 53 & $47.92 *$ & 73.60* \\
\hline & 49 & 30 & $30.96 *$ & 55 & $47.90 *$ & 15 & $20.2 \cdot *$ & $65.20 *$ \\
\hline & 53 & 3 & 6.27 & 11 & 14.12 & 86 & 71.32 & 49.0 . \\
\hline & 56 & 58 & $50.02 *$ & 21 & $27.14^{*}$ & 21 & $18.59 *$ & 21.60 \\
\hline & 57 & 22 & $26.05^{*}$ & 45 & $41.42 *$ & 33 & $34.53 *$ & $68.60 *$ \\
\hline & 66 & 3 & 4.56 & 3 & 4.56 & 94 & 80.88 & 51.80 \\
\hline & 76 & 4 & 8.86 & 3 & 7.75 & 93 & 76.59 & 44.40 \\
\hline & 84 & 4 & 7.14 & 4 & 10.34 & 92 & 75.83 & 46.40 \\
\hline & 85 & 7 & $13.65^{*}$ & 1 & 2.58 & 92 & 75.48 & 46.20 \\
\hline & 88 & 8 & 11.81 & 10 & 13.01 & 82 & $69.77 *$ & $55.20 *$ \\
\hline & 104 & 6 & 10.48 & 1 & 2.58 & 93 & 76.94 & 47.60 \\
\hline & 141 & 1 & 2.58 & 5 & 8.25 & 94 & 80.88 & $57.0 * *$ \\
\hline & 154 & 9 & $13.38 *$ & 1 & 2.58 & 90 & 74.04 & $\begin{array}{c}44.80 \\
\text { (continued to } \\
\text { next page) }\end{array}$ \\
\hline
\end{tabular}


Table 11. (continued from preceding page).

\begin{tabular}{|c|c|c|c|c|c|c|c|c|}
\hline \multirow[t]{2}{*}{ Fusarium } & \multirow{2}{*}{$\begin{array}{c}\text { Isolate } \\
\text { No. }\end{array}$} & \multicolumn{2}{|c|}{ Preemergence damping-off } & \multicolumn{2}{|c|}{ postemergence damping-off } & \multicolumn{2}{|c|}{ survival } & \multirow{2}{*}{$\begin{array}{l}\text { Dry weight } \\
\text { (mg/plant) }\end{array}$} \\
\hline & & $\%$ & Transformed & $\%$ & Transformed & $\%$ & Transformed & \\
\hline \multirow[t]{7}{*}{ F.solani } & 30 & 5 & 9.96 & 2 & 5.17 & 93 & 78.30 & 49.0 \\
\hline & 35 & 5 & 12.92 & 5 & 9.96 & 90 & 72.03 & 42.60 \\
\hline & 50 & 46 & $42.29 *$ & 21 & $24.07 *$ & 33 & $31.70 *$ & $57.60 *$ \\
\hline & 90 & 6 & 10.86 & 16 & $18.45^{*}$ & 78 & $66.01 *$ & 41.80 \\
\hline & $90 / 1$ & 4 & 8.86 & 7 & 11.17 & 89 & 73.89 & 47.20 \\
\hline & 91 & 52 & $46.15^{*}$ & 40 & $39.18^{*}$ & 8 & $16.0 * *$ & $76.40 *$ \\
\hline & 140 & 16 & $15.64 *$ & 6 & 10.83 & 78 & $68.84 *$ & $67.0 * *$ \\
\hline F.lateritium & 2 & 5 & 11.44 & 1 & 2.58 & 94 & 75.98 & 42.20 \\
\hline Control $^{c}$ & $\ldots$ & 0 & 0.00 & 1 & 2.58 & 99 & 87.42 & 29.60 \\
\hline \multicolumn{2}{|c|}{$\operatorname{LSD}(P \leq 0.05)$} & \multicolumn{2}{|c|}{13.29} & \multicolumn{2}{|c|}{14.00} & 16.51 & \multicolumn{2}{|l|}{23.46} \\
\hline \multicolumn{2}{|l|}{$\operatorname{LSD}(P \leq 0.01)$} & \multicolumn{2}{|c|}{17.56} & 18.50 & & 21.82 & 31.01 & \\
\hline
\end{tabular}

a Mean of five replicates (pots).

b percentage data were transformed into arcsine angles before carrying out the analysis of variance to normalize data and

stabilize variances throughout the data range.

* Significant difference from the control.

c Autoclaved soil was mixed with autoclaved sorghum. 
Table 12 . Distribution of pathogenic isolates of Fusarium spp. from flax roots.

\begin{tabular}{|l|c|c|c|c|}
\hline Fusarium sp. & $\begin{array}{c}\text { Total number of pathogenic } \\
\text { isolates }\end{array}$ & $\begin{array}{c}\text { Percentage of isolates within } \\
\text { fungus }\end{array}$ & $\begin{array}{c}\text { Percentage of total } \\
\text { isolates }\end{array}$ & $\begin{array}{c}\text { Percentage of pathogenic } \\
\text { isolates }\end{array}$ \\
\hline F.oxysporum & 8 & 33.33 & 25 & 66.67 \\
\hline F.solani & 4 & 57.14 & 12.5 & 0.00 \\
\hline F.lateritium & 0 & 0.00 & 0.00 & 100.0 \\
\hline Total & 12 & 0.00 & 37.5 & \\
\hline
\end{tabular}

aA total of 32 isolates were tested for pathogenicity on flax seedings ( cultivar Giza 10 ) under greenhouse conditions.14

Table 13. Distribution of Fusarium spp. based on their pathological effects on seedlings of flax cultivar Giza 10 under greenhouse conditions.

\begin{tabular}{|l|c|c|c|c|c|}
\hline \multirow{2}{*}{ Fusarium } & \multirow{2}{*}{$\begin{array}{c}\text { Total number of } \\
\text { tested isolate }\end{array}$} & $\begin{array}{c}\text { Pre emergence } \\
\text { damping -off(\%) }\end{array}$ & $\begin{array}{c}\text { post emergence } \\
\text { damping -off(\%) }\end{array}$ & Survival (\%) & Dry weight \\
\cline { 3 - 6 } F.oxysporum & 24 & 33.33 & 25.0 & 33.33 & 25.0 \\
\hline F.solani & 7 & 42.86 & 42.86 & 57.14 & 42.86 \\
\hline F.lateritium & 1 & 0.00 & 0.00 & 0.00 & 0.00 \\
\hline
\end{tabular}

${ }^{a}$ The tested isolates significantly increased pre- and postemergence damping-off and Dry weight, subsequently significantly decreased survival. 
Table 14. The relative pathogenicity of Fusarium oxysporum and F. solani on flax seedlings (cultivar Giza 10) under greenhouse conditions.

\begin{tabular}{|lcc|}
\hline Fusarium & number of tested isolates & Damping-off (\%) $)^{\text {a }}$ \\
\hline F. oxysprum & 24 & 25.88 \\
\hline F.solani & 7 & 33.94 \\
\hline LSD $(\mathrm{p} \leq 0.05)$ & & N.S. \\
\hline
\end{tabular}

${ }^{a}$ Combined pre- and postemergence damping-off, and each value is the mean of the tested isolates.

Table 15. Correlation among variables used for evaluating pathogenicity of Fusarium spp. Isolates on flax seedlings (cultivar Giza 10) under greenhouse conditions.

\begin{tabular}{|c|c|c|c|c|}
\hline \multirow{2}{*}{ Fusarium } & \multirow[b]{2}{*}{ Variable } & & Variable & \multirow[b]{2}{*}{3} \\
\hline & & $\mathbf{1}$ & 2 & \\
\hline F.oxysporum & 1.preemergence damping -off (\%) & & & \\
\hline \multirow[t]{3}{*}{$(n=24)$} & 2.postemergence damping -off (\%) & $0.320^{\mathrm{a}}(0.127)^{\mathrm{b}}$ & & \\
\hline & 3.Survival (\%) & $-0.688(0.000)$ & $-0.908(0.000)$ & \\
\hline & 4.Dry weight (mg/plant) & $-0.212(0.320)$ & $-0.091(0.672)$ & $0.164(0.445)$ \\
\hline F.solani & 1.preemergence damping -off (\%) & & & \\
\hline \multirow[t]{3}{*}{$(n=7)$} & 2.postemergence damping -off (\%) & $0.865(0.012)$ & & \\
\hline & 3.Survival (\%) & $-0.979(0.000)$ & $-0.949(0.001)$ & \\
\hline & 4.Dry weight (mg/plant) & $0.784(0.037)$ & $0.658(0.108)$ & $-0.759(0.048)$ \\
\hline All fusariac & 1.preemergence damping -off (\%) & & & \\
\hline \multirow[t]{3}{*}{$(n=32)$} & 2.postemergence damping -off (\%) & $0.386(0.029)$ & & \\
\hline & 3.Survival (\%) & $-0.778(0.000)$ & $-0.880(0.000)$ & \\
\hline & 4.Dry weight (mg/plant) & $0.100(0.587)$ & $0.016(0.933)$ & $-0.062(0.736)$ \\
\hline
\end{tabular}

a Pearson's correlation coefficient.

b Probability level.

${ }^{\mathrm{c}}$ All fusaria included F. oxysporum (24 isolates), F.solani (seven isolates), and F.lateritium (one isolate) 


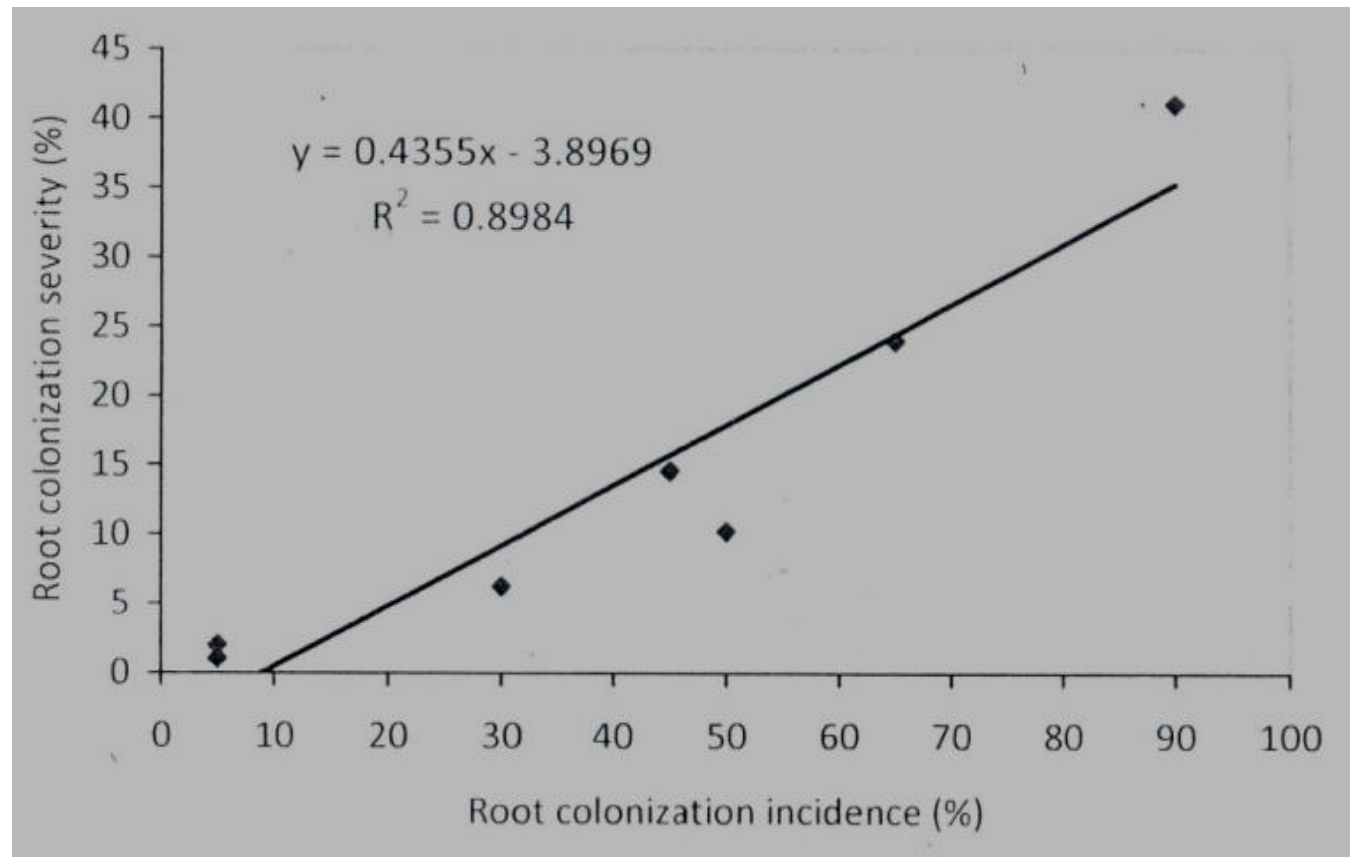

Fig. 1. Relationship between root colonization incidence and severity of flax plants infected with Fusarium spp. and other fungi involved in postemergence damping-off and root rot.

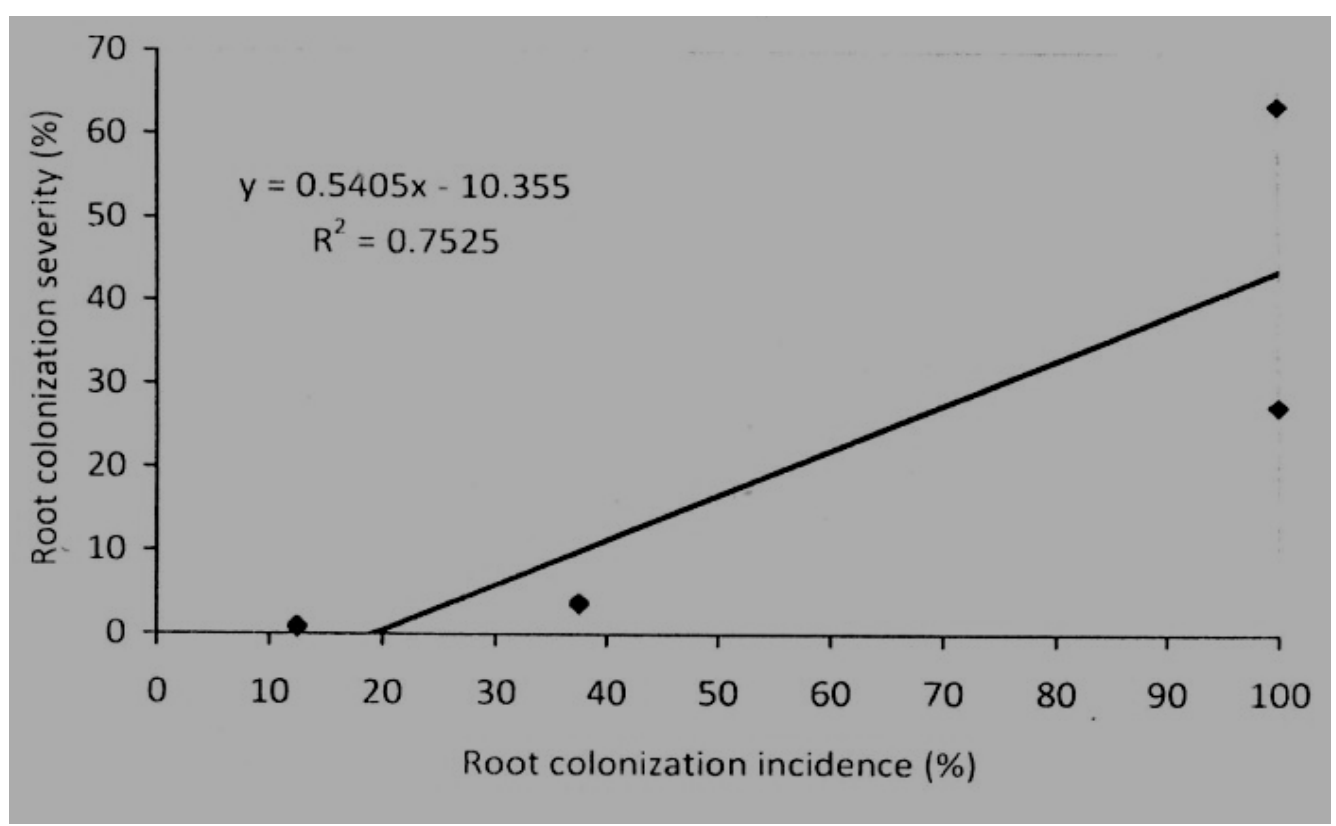

Fig. 2. Relationship between root colonization incidence and severity of flax plants infected with Fusarium spp. involved in postemergenc damping-off and root rot. 


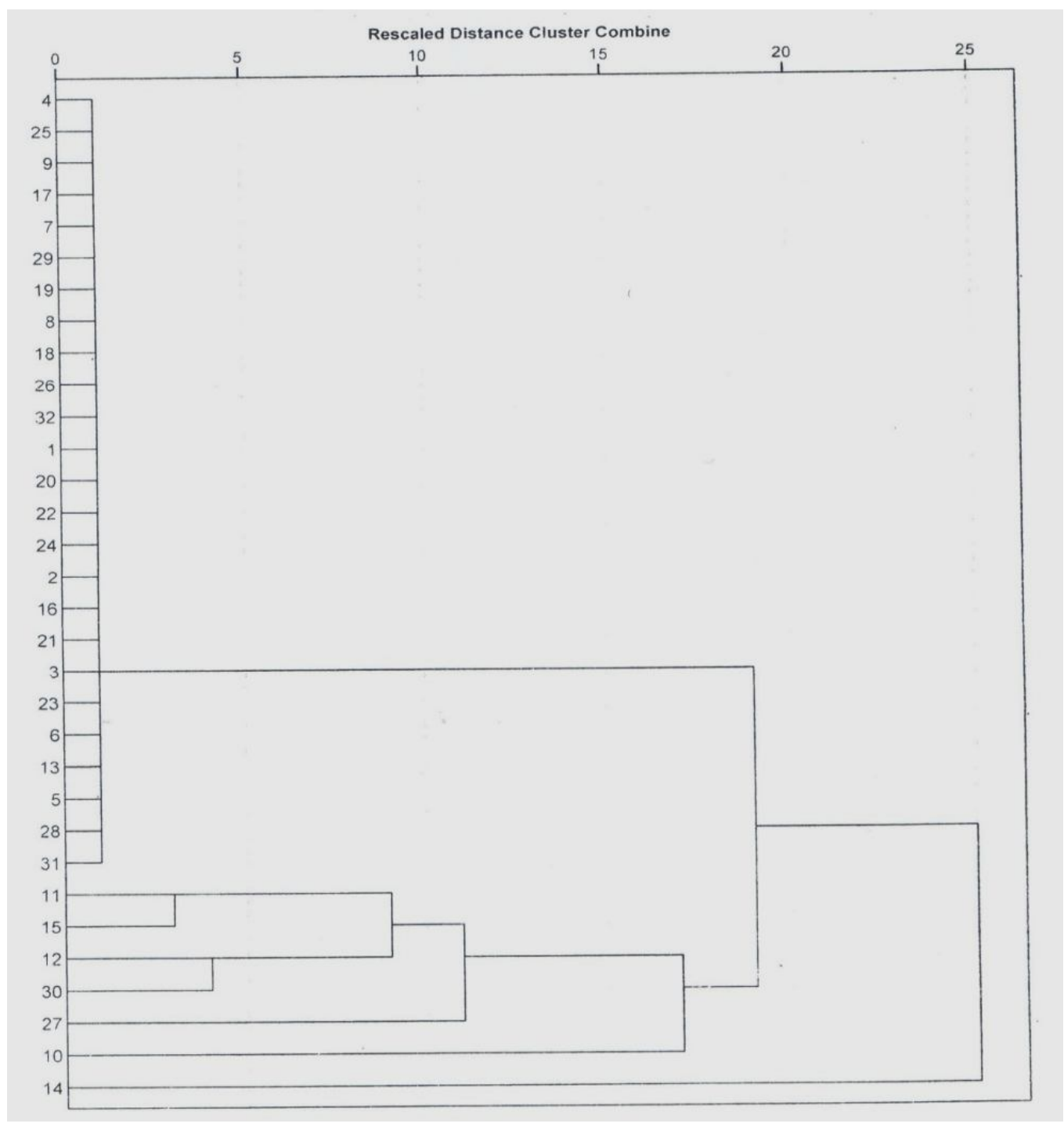

Fig. 3. Phenogram based on average linkage cluster analysis of virulence of 32 isolates of Fusarium spp. on flax seedlings (cultivar Giza 10) under greenhouse conditions. Virulence of the isolates was evaluated based on preand postemergence damping-off, survival, and dry weight. Identification of the tested Fusarium spp isolates and their geographic origins are shown in Table 10. 


\section{REFERENCES}

1. Alabouvette C., B., Schippers P., Lemanceau Bakker P.A.H.M. 1998. Biological control of Fusarium wilts. In: plant-Microbe Interactions and Biological control. (eds GJ. Boland, LD. Kuykendall). Marcel Dekker, New York. 15-36.

2. Booth, C. 1971. The Genus Fusarium. Commonwealth Mycological Institute, kew, Surrey, England. 237.

3. Burgess, LW. 1981. General ecology of the fusaria. In: Fusarium - Diseases, Biology, and Taxonomy. (eds PE Nelson, TA Toussoun, RJ Cook). Pennsylvania State University press, PA. 225-235.

4. El-Hawary, O.G. Omar M.R., Hussein E.M., Mosa A.A., Mostafa M.H. 2008. Characterization of pathogenicity of Rhizoctonia solani isolates involved in seedling blight of flax. Mansoura Journal of Agricultural Science 33, 1801-1811.

5. Gilman, JC. 1966. A Manual of Soil Fungi. $2^{\text {nd }}$ Ed. The Iowa State University Press,Iowa. 450.

6. Gomez, K.A., Gomez A.A. 1984. Statistical procedures for Agricultural Research, $2^{\text {nd }}$ Ed.John Wiley and Sons Ltd,New York.680.

7. Gordon, WL. 1956. The occurrence of Fusarium species in Canada. V. Taxonomy and geographic distribution of Fusarium species in soil. Canadian Journal of Botany 34, 833-846.

8. Gruzdeviene, E, Brazauskiene I, Repečkiene J,Lugauskas A. 2008. The occurrence of pathogenic fungi during flax growing season in central Lithuania. Journal of Plant Protection Research 48,255-265.

9. Khalil, MS, Aly AA, El-kady EA, Eisa HA.1992. impact of chemical control of flax seedling blight on seed rate,yield and yield components. Menofiya Journal of Agriculture Research 17,1713-1727.

10. Killebrew, JF , Roy KW, Abney TS. 1993. fusaria and other fungi on soybean seedlings and roots of older plants and interrelationships among fungi , symptoms, and soil characteristics

11. Kuldau, GA, Yate IE. 2000. Evidence for Fusarium endophytes in cultivated and wild plants. In Microbial Endophytes.( eds CW Bacon, JF White).Marcel Dekker, New York.85-117. 
12. Leslie, JF, Summerell BA. 2006. Fusarium Laboratory Manual. Blackwell publishing, Ames, IA.

13. Martens, JW, Seaman WL, Atkinson TG. 1984. Diseases of Field Crops in Canada. Canadian Phytopathological Society, pp.160.

14. Meyer, JA. 1967. Recherches sur les Fusariose. II. Ecologie et pathoegenie du Fusarium oxysporum. Annals des Epiphyties 18, 241-247.

15. Nelson, SG, Campbell CL. 1992. Incidence and patterns of association of pathogens of a leaf spot disease complex on white clover in the Piedmont region in North Carolina. Phytopathology 82, 1013-1021.

16. Nyvall, RF. 1981. Field Crop Diseases Handbook. Avi Publishing Company, INC, Connecticut. 436.

17. Ogoshi, A. 1987. Ecology and pathogenicity of anastomosis groups of Rhizoctonia solani küln. Annual Review of Phytopathology 25,125-143.

18. Rouse, DI, Mackenzie DR, Nelson RR, Elliott VJ. 1981. Distribution of wheat powdery mildew incidence in field plots and relationship to disease severity. Phytopathology 71, 1015-1020.

19. Seem, RC. 1984. Disease incidence and disease severity relationships. Annual Review of phytopathology 22, 133-150.

20. Summerell, BA, Salleh B, Leslie JF. 2003. A utilitarian approach to Fusarium identification. Plant Disease 87, 117-128.

21. Tunali, B, Nicol JM, Hodson D, Uckun Z, Büyük $O$, Erdurmus D, Hekimhan $H$, Aktas H, Akbudak MA, Bağcl SA. 2008. Root and crown rot fungi associated with spring, facultative, and winter wheat in Turkey. Plant Disease 92, 1299-1306. 


\title{
تصنيف وتقيم القدرة المرضية لأنواع الفيوزاريوم المعزولة من جذور الكتان
}

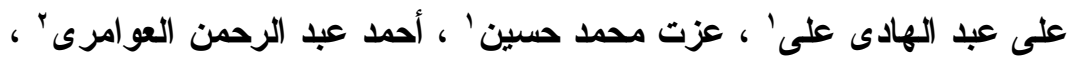

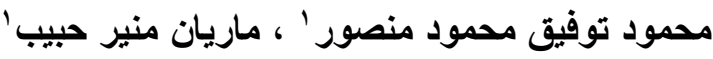

\author{
ا ـ معهد بحوث امراض النباتات ،مركز البحوث الزراعية ، الجيزة ، مصر. \\ r ـ قسم النبات، كلية العلوم ، جامعة عين شمس، القاهرة ، مصر .
}

عزلت سبعة فطريات من الأنسجة الميته لجذور بادرات الكتان أو النباتات البالغة. العينات المستعملة فى العزل جمعت بطريقة عشوائية من القطع التجريبية المزروعة بالكتان فى محطة التهنة

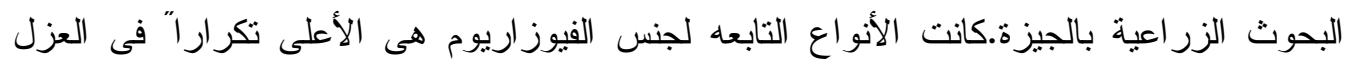

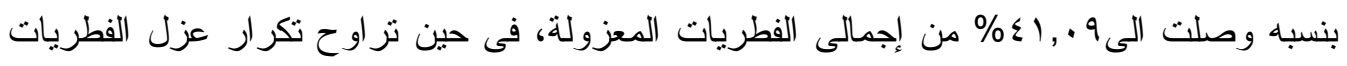

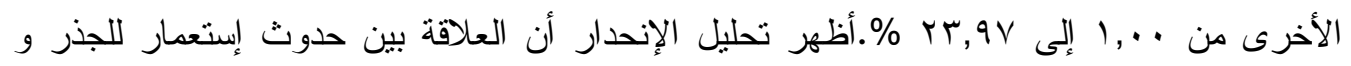
شدة إستعمار الجذر بو اسطة الفطريات المعزولة هى علاقة خطية ـ أظهر نموذج الإنحدار المتحصل

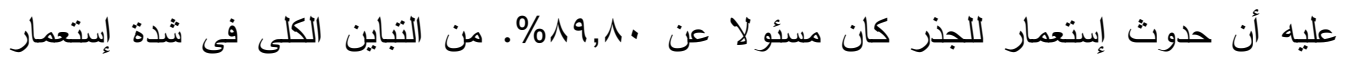

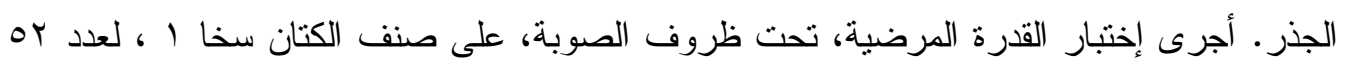

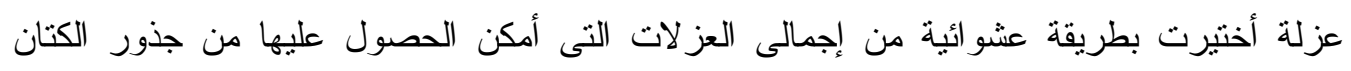

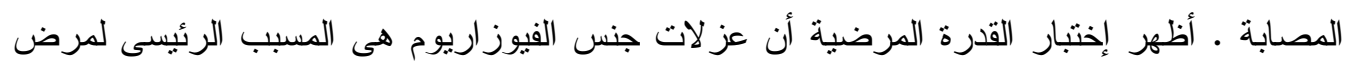

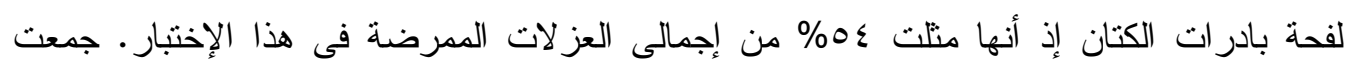

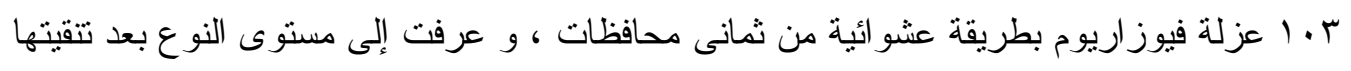

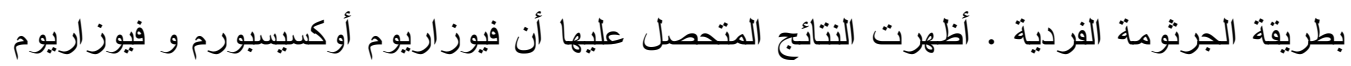

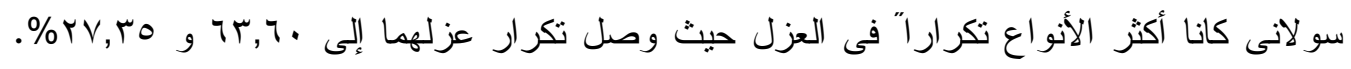

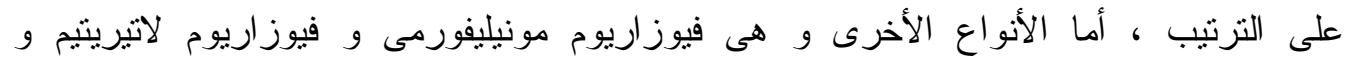

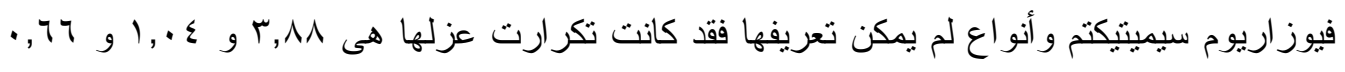

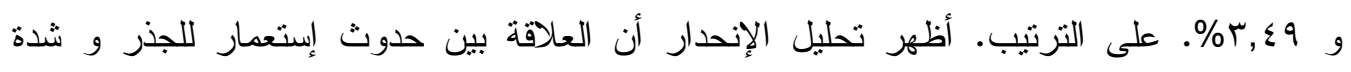

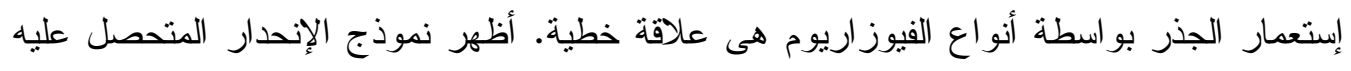

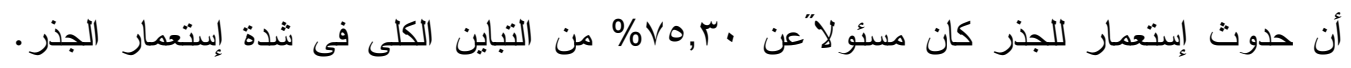

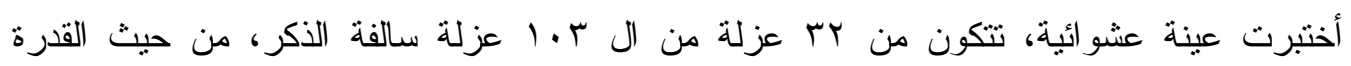

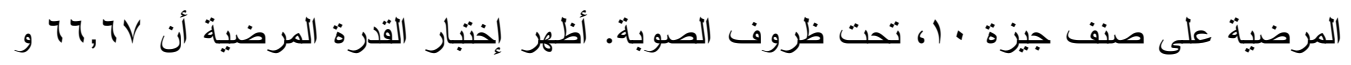

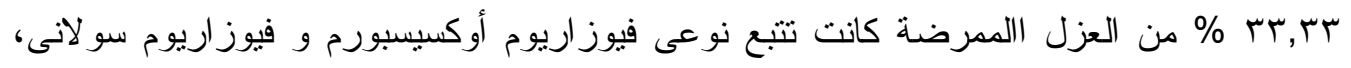

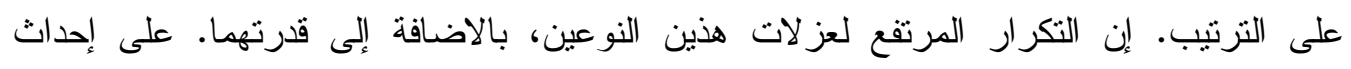

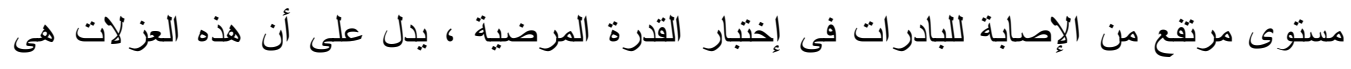

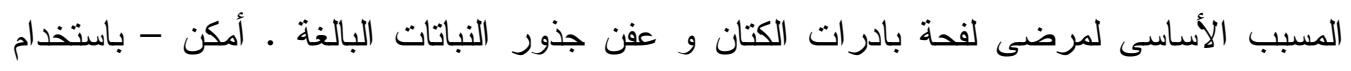

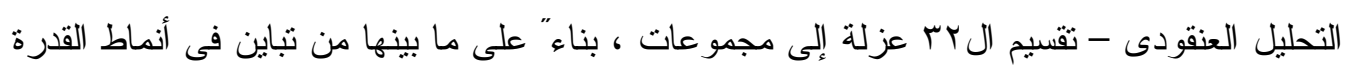

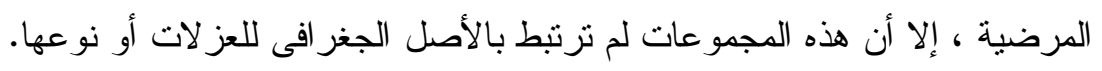

